\title{
Characterization of the Fish Population in the Southwestern Part of the Onega Lake (Karelia) Based on the Results of Long-Term Monitoring
}

\author{
Irina Mikhailovna Dzyubuk* \\ Institute of Biology, Ecology and Agrotechnologies, Petrozavodsk State University, 33 Lenin Ave., Petrozavodsk, 185910, Russia
}

Received: 28/06/2020

Accepted: 27/09/2020

Published: 20/12/2020

\begin{abstract}
The results of the long-term ichthyological studies of the southwestern part (the Sheltozero - Brusno region) of the Onega Lake performed as part of the environmental monitoring have been presented. This is one of the most productive and clean areas in the lake. The fish population of the southwestern part of the Onega Lake includes 20 fish species that are representatives of 10 families belonging to six faunistic complexes. By the number of the species, the Carp family dominates. By the number of the species in this area of the lake, the Arctic freshwater, the boreal plain, and the boreal foothill complexes are equally important. The species of the freshwater Pontian, the Arctic marine, and the ancient Late Tertiary complexes together amount to no more than $25 \%$ of the total population. In the southwestern region of the lake, there are many valuable commercial species (freshwater salmon (Salmo salar Linnaeus, 1758), lavaret (Coregonus lavaretus lavaretus (Linnaeus, 1758)), pikeperch (Sander lucioperca (Linnaeus, 1758)), pike (Esox lucius Linnaeus, 1758), etc. Smelt (Osmerus eperlanus (Linnaeus, 1758)) and vendace (Coregonus albula (Linnaeus, 1758)) are the most commercially valuable (75 - $85 \%)$. The populationecological analysis has shown a relatively good state of most studied fish species. For maintaining the existing structure and state of the fish population in the southwestern part of the Onega Lake, a set of measures is required, including the preservation and improvement of the fish habitat, the conditions for the fish reproduction and feeding; toughening the protective measures during periods with a decrease in the number of fish species; regulation of fishing, and increasing the amount of fish artificial reproduction, rearing, and releasing into the lake.
\end{abstract}

Keywords: Fishing, fish population, ecological monitoring, population

\section{Introduction}

Currently, the relevance of studying the fish population of freshwater lakes prone to anthropogenic impact remains high [16]. The Onega Lake, the second largest lake in Europe, is valuable in terms of energy, socio-economic, and environmental significance for the development of the North-West of Russia. The fish resources of the Onega Lake have always been and will remain attractive not only for commercial fishermen and local fisherfolk but also for tourists. However, the state of this largest fishery pond largely depends on the way these resources are used. It is known that irrational, unmonitored fishing decreases the population and causes the disappearance of valuable commercial species (sturgeon, salmon, lavaret, etc.). The same consequences occur when the quality of the aquatic environment changes. Salmon population in the southwestern part of Onega Lake, the size of which was catastrophically small due to excessive fishing, was thoroughly researched. The results of the conducted research showed that more than $50 \%$ of the catches were artificially bred fish, i.e. one of the most effective ways to preserve the species in the lake was intensive fish breeding at hatcheries [7-9].

Successful existence of fish populations depends on the quality of the lake's aquatic environment, which is deteriorated due to exerted technogenic, anthropogenic impact. The fish population is sensitive to any changes of aquatic environment. In the southwestern part of Onega Lake, i.e. in its cleanest area, anthropogenic influence manifested itself in the organization and functioning of the trout cage farm. The author's studies have shown that the operation of the cage farm could cause changes in the state of the aquatic ecosystem and the species composition of fish in certain areas of the southwestern part of Lake Onega [1011]. Therefore, there are urgent tasks of preventing pollution, eutrophicating the water, optimizing capture fishing, and developing measures aimed at maintaining the state of the fish population in the Onega Lake at the optimal level. The study has been aimed at assessing the ecological and biological state of the fish population in the southwestern part of the Onega Lake (Karelia) based on the results of long-term monitoring.

\section{Materials and methods}

The object of the study was the fish population of the

Corresponding author: Irina Mikhailovna Dzyubuk, Institute of Biology, Ecology and Agrotechnologies, Petrozavodsk State University, 33 Lenin Ave., Petrozavodsk, 185910, Russia. E-mail: dzyubuk.i.m@mail.ru 
southwestern part of the Onega Lake (the Sheltozero - Brusno region). The fish were caught in 1998 - 2016 from May to October. The fishing gear was nets (with the mesh of 10 to 70 $\mathrm{mm}$ ), seine nets (drag nets, tickler chains), and trail nets. A total of about four thousand specimens of various fish species were studied.

During the studies, the species composition of the fish in the catches, the age, sex, size, and weight of the fish were determined. The Latin name of the fish families and species are given according to the literature sources widely used in ichthyological research in Russia [12-14]. The fauna associations were given as per G. N. Nikolsky [15]. The fish were weighed, measured, their age was determined, and the fish were opened using the standard methods [16,17]. The caught fish were measured using a tape measure and a beam caliper and weighed using an electronic and a pharmacy weigher, depending on the size of the fish. The age was determined using an MBS-6 binocular microscope and the slices of scales, otoliths, and gill covers. To determine the age of salmonids, whitefish, cyprinids, and other fish species, scales were sampled; for control, otoliths were sampled from ruffe and smelt, as well as gill covers -from perch. When preparing samples, a $10 \%$ ammonia solution was used, in which the recording structures (scales, gill covers) were kept for 10-15 minutes. Then they were placed on glass slides and examined under a binocular microscope.

All measurements, including weighing, determination of the age of the fish population, etc., were carried out personally by the author of the article (one researcher) during multi-year monitoring, which increases the reliability of the results obtained. The author personally prepared and examined about 7,000 samples by which the age of the fish was determined. On the basis of the obtained results of the absolute indicators of the length and mass of fish, the dynamics of the absolute indicators for a longterm period, the change in the growth rate, the increments in length and weight during ontogeny were assessed. Based on the study of the age composition of fish in the catches, its changes in the long-term aspect were traced. When the fish were dissected, the sex of the individuals was determined; on the basis of this, the sex composition of the fish population and its dynamics were estimated. The collected data were processed using the standard methods of analysis of variance [18,19].

\section{Results and discussion}

The Onega Lake stretches out from the north-west to the south-east. The total water area of the lake with islands is $9,943.3$ $\mathrm{km}^{2}$, without islands $-9,692.6 \mathrm{~km}^{2}$. Its maximum length is 290 $\mathrm{km}$; its width is $82 \mathrm{~km}$. The average depth of the lake is $30 \mathrm{~m}$, the greatest depth is $120 \mathrm{~m}$; the depths of 20 to $40 \mathrm{~m}$ prevail. Over 50 rivers and small rivers and about 1,000 streams fall into the Onega Lake. The major tributaries are the Vodla, Shuja, Suna, and Andoma Rivers. The largest bays of the Onega Lake are the Petrozavodsk and the Kondopoga Bays, which have been exposed to intense anthropogenic effect [20,21].

The southwestern part of the Onega Lake in the Sheltozero Brusno region is one of the purest areas of the water body. All water masses of the Onega Lake pass through this area; it is connected with the Ladoga Lake, and through the Neva River with the Baltic Sea. The water of the southwestern part of the
Onega Lake belongs to the hydrocarbonate class of the calcium group.

The color of the water is $20-25$ degrees; it can reach $40-50$ degrees. The active reaction of the medium is in the range between 7.0 and 7.8. The content of oxygen is not less than 9.5 $\mathrm{mg} / \mathrm{l}$. The content of nutrients is not high (the maximum concentration of mineral phosphorus is $0.01 \mathrm{mg} / \mathrm{l}$, of ammonia nitrogen $-0.33 \mathrm{mg} / \mathrm{l}$ ). The water masses in the southwestern area of the lake retain an oligotrophic nature [22]. The fish population of the Onega Lake includes 35 species belonging to 15 families [21]. The southwestern part of the Onega Lake (the Sheltozero Brusno region) is populated by 20 fish species ( $57 \%$ of the total number of the species in the lake) (Table 1).

It is known from the local population that sometimes eel (Anguilla anguilla (Linnaeus, 1758)), chub (Leuciscus cephalus (Linnaeus, 1758)), rudd (Scardinius erythrophthalmus (Linnaeus, 1758)), and blue bream (Abramis ballerus (Linnaeus, 1758)) are found in the catches in this area. Some fish species in the southwestern part of the Onega Lake (the Sheltozero - Brusno region) are represented by various ecological forms. Of the lavaret, Coregonus lavaretus widergeni tsholmygensis and Coregonus lavaretus lavaretus ludoga $n$. Onegi are met. Salvelinus lepechini (Gmelin, 1788)) and Salvelinus lepechiniprofundicola Berg are also found. The large form of whitefish, European cisco (Coregonus albula kiletz. Michalowsky), is also met.

By the number of the species, the Carp family dominates (five species). The Salmonidae and Percidae families include three species each, the Coregonidae and Gasterosteidae - two species each, and the Thymallidae, Osmeridae, Esocidae, Lota, and Cottidae are represented by one species each. The species in the southwestern part of the lake belong to six faunistic complexes. By the number of the species, the leading position is taken by the Arctic freshwater, boreal plain, and boreal foothill complexes ( $25 \%$ each). The freshwater Pontian and arctic marine complexes account for $10 \%$ each, and the ancient Late Tertiary complex accounts for $5 \%$ (Fig. 1 ).

Further long-term and systematic studies of the species composition of fish in Lake Onega will allow assessing the stability of the state of faunistic complexes and the fish community of the aquatic ecosystem. The population-ecological analysis revealed the relatively favorable state of the feeding school (Shuiskoye) of freshwater salmon (Salmo salar morpha sebago Girard) in the southwestern part of the lake. In the catches, the share of commercially reproduced fish reached $53 \%$. No significant difference was found between naturally and commercially reproduced fish in terms of the size and weight, which were in the range of $33.5-88.0 \mathrm{~cm}$ and $0.4-8.8 \mathrm{~kg}$. The studies showed a significant reduction in the maximum age of two ecological forms of lavaret - fera (C. l. ludoga natio onegi) and pit lavaret $(C$. l. widegreni natio tscholmugensis $)$ - in catches at the age of $11+$ to $7+$ years and $15+$ to $9+$ years, respectively. The length of fera (C. l. ludoga natio onegi) in the catches of 1999 had been up to $55 \mathrm{~cm}$, and its weight was up to $1.5 \mathrm{~kg}$; in 2016, these indicators in the specimens of the same age did not exceed $40 \mathrm{~cm}$ and $800 \mathrm{~g}$, respectively. For pit lavaret (C. l. widegreni natio tscholmugensis) the maximum length and weight in this period had also decreased from $63 \mathrm{~cm}$ to $50 \mathrm{~cm}$ and from $3.1 \mathrm{~kg}$ to $2 \mathrm{~kg}$, respectively. 
Table 1: Fish species in the southwestern part of the Onega Lake

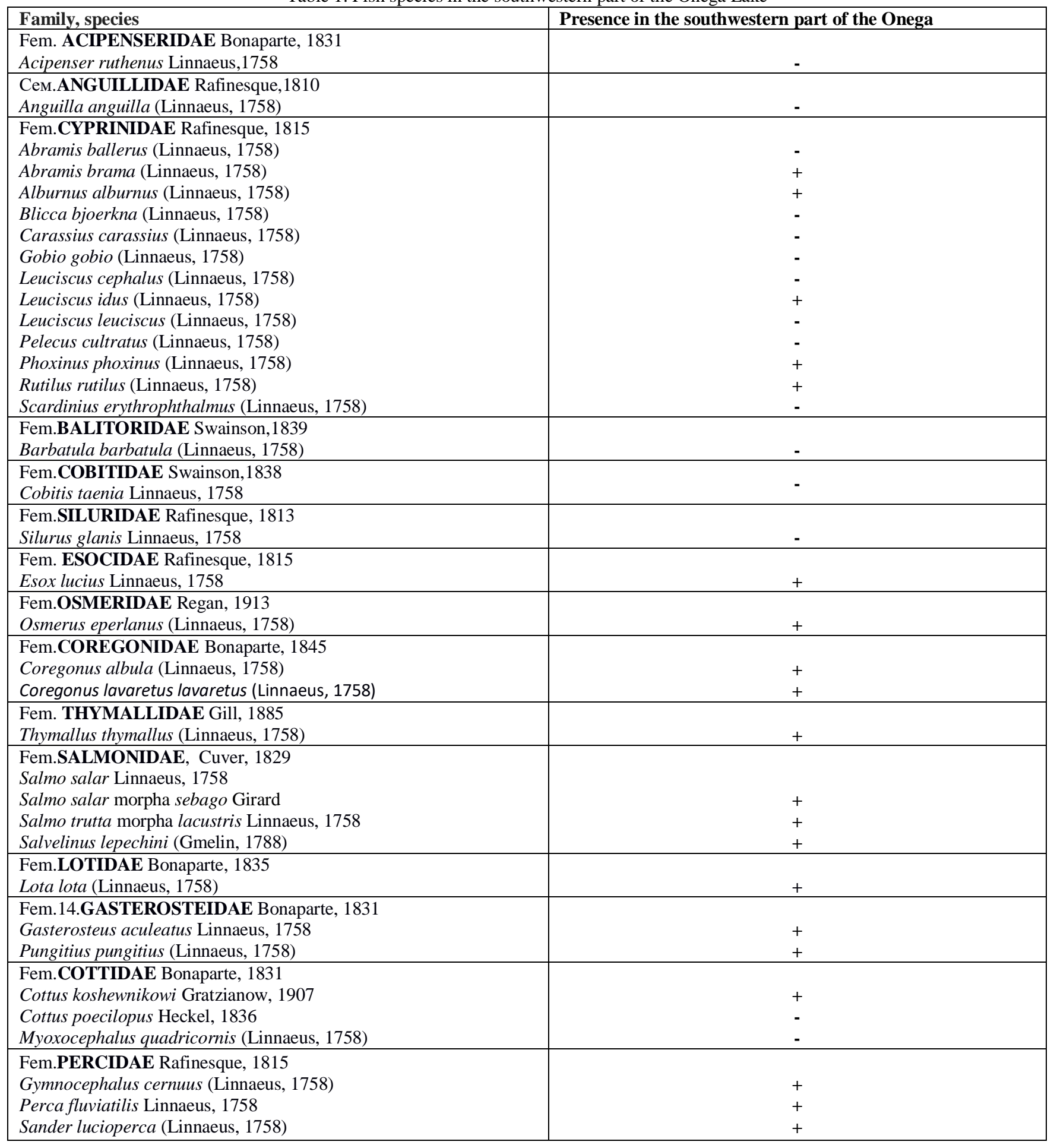

The differences were also significant in the same age groups of different generations. The increased catching and the focus of lavaret catching on larger specimens had caused changes in the age structure of lavaret populations in this area of the lake. It may be assumed that changes occurred in the feed base of the species, which affected its size and weight. Currently, the issue of preserving lavaret in the water bodies in Karelia is very urgent. This requires continuing the introduction of lavaret $(C . l$. Lavaretus (L)) to water bodies, breeding the species at fish farms, preserving (improving the disturbed) habitat, and reducing the catching load on this valuable commercial species. 


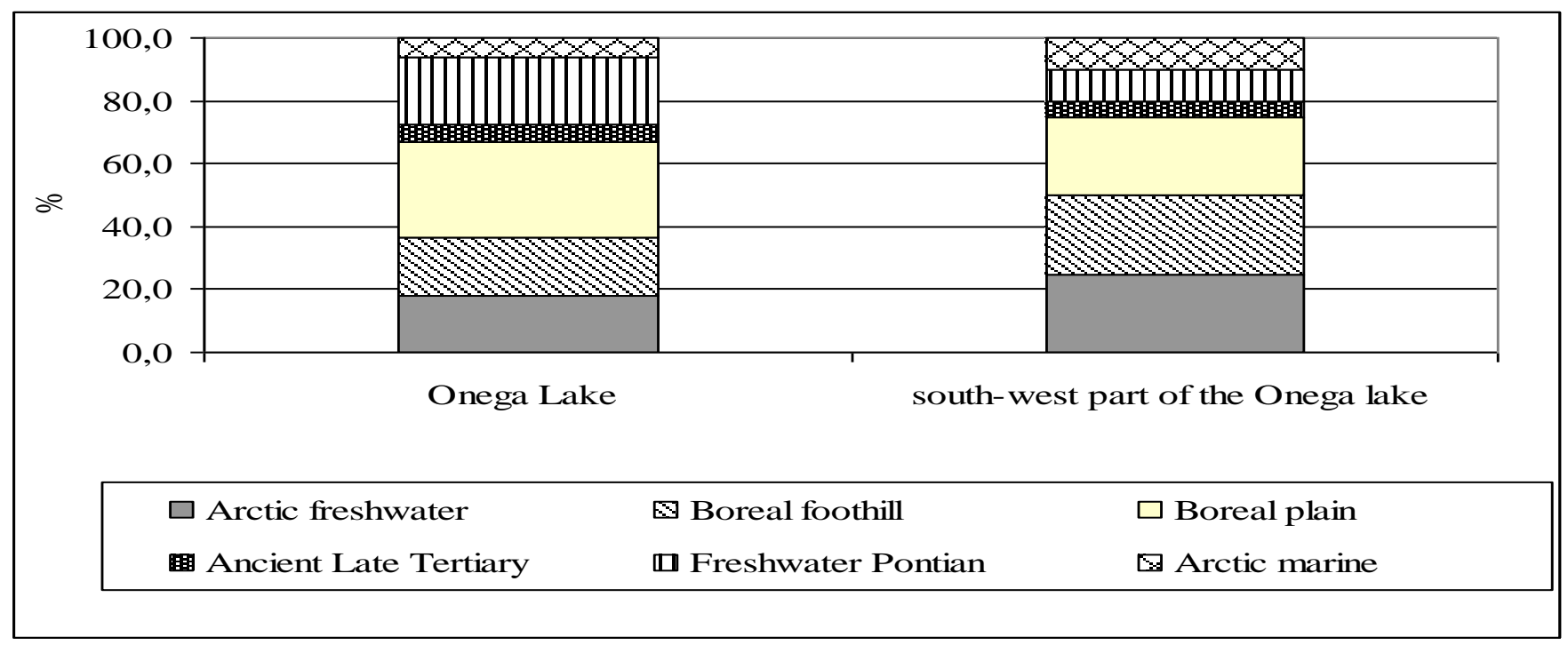

Figure 1: The ratio of faunistic complexes by fish species in catches in the southwestern part of the Onega Lake

The most important place in the fish resources of the lake is taken by whitefish (C. albula (L)). Its maximum age in commercial catches in the Onega Lake is five years; the life expectancy does not exceed six years. Until the end of the 1980s, two-year-olds $(1+)$ and three-year-olds $(2+)$ had been of primary importance in the catches, later, four-year-olds $(3+)$ and fiveyear-olds (4+) became of primary importance. This might be the result of the improved conditions for reproduction and feeding due to eutrophication of certain areas in the lake and a decrease in the pressure of predators (mainly salmon ( $S$. salar morpha sebago Girard) in the southwestern part of the lake) due to their intensified catching.

The Sheltozero region is one of the main distribution locations of the large form of vendace - European cisco (C. $a$. kiletz. Michalowsky). Due to their scarcity, large commercial catches of this species are rarely observed. The authors managed to catch and process only 70 European ciscos at the age of $3+$ to 9+ years, although the maximum age of European cisco (C. $a$. kiletz. Michalowsky) is 20 years. The fish aged 5+ to 7+ years prevailed in the catches. The maximum size and weight of the fish were $39.7 \mathrm{~cm}$ and $570 \mathrm{~g}$, respectively. Vendace (O. eperlanus $(\mathrm{L}))$ is numerous in the southwestern part of the lake, which is also due to the presence of spawning grounds. It was found that the age limit of vendace (O. eperlanus $(\mathrm{L}))$ had increased from $8+$ (before 1995) to 10+ years (after 2003). This was the result of improving the habitat conditions for the species in this area of the lake. The size and weight of vendace (O. eperlanus $(\mathrm{L})$ ) in the southwestern part of the lake have been stable over the past decade.

Pike (E. lucius L.) was one of the main objects of commercial and recreational fishing. In the trawl catches, pike age was 14+ years; its length reached $104 \mathrm{~cm}$, and the weight was more than $10 \mathrm{~kg}$. The age composition, the size, and the weight of pike (E. lucius L.) in the catches remained stable, which was associated with a sufficient feed base (a large population of small invaluable fish). It is believed that as a rule, freshwater predatory fish have a small population size [23]. However, pike (E. lucius L.) is highly resilient and can remain highly abundant in the water body in favorable conditions for living and reproduction with the absence of uncontrolled catching. Bream (A. brama (L)) is one of the most important commercial species in Karelia. In the Onega Lake, bream has a long life cycle of $29-30$ years. In the studies of the authors, no specimens older than 20+ years, longer than $45 \mathrm{~cm}$, and weighing more than $1,600 \mathrm{~g}$ were found. Over many years, bream age composition and the size and weight parameters were stable. The study showed a reduction in the age of pikeperch $(S$. lucioperca (L)) in the catches at the age of $31+$ to $20+$ years from 1950 until the present. The population of pikeperch (S. lucioperca $(\mathrm{L}))$ in the lake is not limited by the feed base since the reserves of vendace $(O$. eperlanus $(\mathrm{L}))$ and whitefish $(C$. albula $(\mathrm{L}))$ are sufficient. In the past century, pikeperch (S. lucioperca $(\mathrm{L}))$ could reach the length of $80 \mathrm{~cm}$ and the weight of $7 \mathrm{~kg}$; currently, its size and the weight do not exceed $66 \mathrm{~cm}$ and $4,510 \mathrm{~g}$, respectively.

In terms of the age, size, and weight characteristics, the stable state of roach ( $R$. rutilus $(\mathrm{L}))$, striped perch (P. fluviatilis L.), Eurasian ruffle (G. cernuus (L)), and other invaluable fish was noted in this region of the Onega Lake. Vendace (O. eperlanus (L)) $(79 \%)$ and whitefish (C. albula $(\mathrm{L}))(7 \%)$ prevailed in the research catches in the southwestern part of the Onega Lake (the Sheltozero - Brusno region). Lavaret (C. l. lavaretus (L)) and eelpout (L. lota $(\mathrm{L}))$ account for a large share in the catches $(7.5 \%)$. Striped perch (P. fluviatilis L), Eurasian ruffle $(G$. cernuus $(\mathrm{L})$ ), roach $(R$. rutilus $(\mathrm{L}))$, and other small fish are quantitatively much inferior to vendace $(O$. eperlanus $(\mathrm{L}))$ (about $10 \%)$. Pikeperch (S. lucioperca $(\mathrm{L}))$, bream (A. brama $(\mathrm{L}))$, pike (E. lucius L), and grayling (T. thymallus (L)) are even less common in the catches (up to $10 \%$ ). This region remains a place for feeding freshwater salmon ( $S$. salar morpha sebago Girard) of the Shuya school, whose strength is mainly determined by the amounts of reproduction in the artificial conditions. Single rainbow trouts (Oncorhynchus mykiss irideus (Walbaum, 1792)) that left the cages as a result of emergencies at trout farms are found in the catches.

\section{Conclusions}

The development of fisheries in the water bodies of Karelia 
depends in many respects on successful resolving of the tasks of preserving the fish habitat, optimizing capture fishing, especially in large water bodies with a significant number of valuable commercial species, and maintaining the state of the fish population in the lakes at the optimal level. All this is also characteristic of the largest fishery reservoir, the Onega Lake, which is rich in fish resources and has favorable living conditions for valuable commercial species. As a result of the Onega Lake monitoring study (1998 to 2016), materials were obtained about the state of the fish population in one of the most productive and the cleanest part of the lake, the southwestern one. The fish population of the southwestern part of the Onega Lake (the Sheltozero - Brusno region) includes 20 fish species (57\% of the total number of species in the lake), representatives of 10 families (66\% of the number of families characteristic of the lake) belonging to six faunistic complexes. In terms of the number of species, Cyprinidae (five species) are dominating, followed by Salmonidae and Percidae (three species) and Coregonidae and Gasterosteidae (two species). Thymallidae, Osmeridae, Esocidae, Lota, and Cottidae are represented by one species each. By the number of the species, the Arctic freshwater, boreal plain, and boreal piedmont complexes are equally important ( $25 \%$ each). The freshwater Pontian, Arctic marine, and ancient Late Tertiary complexes together constitute no more than $25 \%$.

The population-ecological analysis showed the relatively good state of most studied fish species in the southwestern part of the Onega Lake (the Sheltozero - Brusno region). A large number of valuable commercial species inhabit the southwestern region of the lake, but vendace (O. eperlanus $(\mathrm{L})$ ) remains predominant in commercial catches in this region of the lake. The catches of whitefish $(C$. albula $(\mathrm{L})$, lavaret $(C$. l. lavaretus $(\mathrm{L}))$, and burbot $(L . \operatorname{lota}(\mathrm{L}))$ are 10 times lower. The catches of perch (P. fluviatilis L), pikeperch (S. lucioperca $(\mathrm{L}))$, Eurasian ruffle ( $G$. cernuus $(\mathrm{L})$ ), roach $(R$. rutilus $(\mathrm{L})$, bream $(A$. brama $(\mathrm{L}))$, pike (E. lucius $\mathrm{L})$, and grayling (T. thymallus $(\mathrm{L})$ ) are relatively low. To maintain the well-being of the populations of valuable commercial species, fish-breeding activities (commercial reproduction of fish, release of juveniles into the natural environment, etc.) are of great importance. With such measures, it is possible to preserve freshwater salmon ( $S$. salar morpha sebago Girard) in the southwestern part of the lake. It is necessary to reduce the fishing load on whitefish (C. l. lavaretus (L)) and to continue its commercial reproduction, introduction, and use as an object of breeding at fish farms.

\section{Ethical issue}

Authors are aware of, and comply with, best practice in publication ethics specifically with regard to authorship (avoidance of guest authorship), dual submission, manipulation of figures, competing interests and compliance with policies on research ethics. Authors adhere to publication requirements that submitted work is original and has not been published elsewhere in any language.

\section{Competing interests}

The authors declare that there is no conflict of interest that would prejudice the impartiality of this scientific work.

\section{Authors' contribution}

All authors of this study have a complete contribution for data collection, data analyses and manuscript writing.

\section{References}

1. Dzyubuk IM, Klyukina EA. Otsenka mnogoletnei dinamiki vidovogo sostava rybnogo naseleniya malykh ozer Karelii s pomoshchyu metodov matematicheskoi statistiki [Assessment of the long-term dynamics of the species composition of the fish population of small lakes in Karelia using the methods of mathematical statistics]. Scientific notes of Petrozavodsk State University. 2016 Mar; 2(155):63-69.

2. Dzyubuk IM, Klyukina EA. Sovremennoe biologicheskoe sostoyanie massovykh vidov ryb ozera Konchezero (Kareliya) [The modern biological state of mass fish species of the Konchezero Lake (Karelia)]. News of the Samara Scientific Center of the Russian Academy of Sciences. 2018; 20(5):104-109.

3. Moore JW, Olden JD. Response diversity, nonnative species, and disassembly rules buffer freshwater ecosystem processes from anthropogenic change. Global Change Biology. 2017;23(5):1871-1880. Available from:https://doi.org/10.1111/gcb.13536

4. Sterligova OP, Ilmast NV, Milyanchuk NP. Rybnoe naselenie malykh vodoemov basseina Onezhskogo ozera i perspektivy ikh ispolzovaniya.[Fish population of small water bodies of the Onega Lake basin and the perspectives of their use]. Proceedings of the Karelian Research Centre of Russian Academy of Sciences. 2018; 10 96-104.

5. Estevan LdaS, Ballester ELC, Costa KAda, Scheffer EWdeO, Vazdos-Santos, AM. Fish community response to environmental variations in an impacted Neotropical basin. Ecology of freshwater fish. 2018; 27(4):1126-1139. Available from: doi:10.1111/eff.12420

6. Ngor PB, Grenouillet G, Phem S, So N, Lek S. Spatial and temporal variation in fish community structure and diversity in the largest tropical flood-pulse system of South-East Asia. Ecology of freshwater fish. 2018; 27(4):1087-1100. Available from: doi:10.1111/EFF.12417

7. Ryzhkov LP, Krupen IM, Elesova NG. Morphophysiological characteristics of salmon of Lake Onego. Proceedings of the Fourth International Lake Ladoga Symposium. Joensuu 2002; pp. 554 -559.

8. Ryzhkov LP, Krupen IM. Morpho-physiological features of lakefeeding Salmon from lake Onego. Atlantic salmon: biology, conservation and restoration. Petrosavodsk, 2003.

9. Dzyubuk IM, Ryzhkov LP. Dinamika sostoyaniya ihtiofauny Onezhskogo ozera $v$ XX veke. [Dynamics of the state of the ichthyofauna of the Onega Lake in the XX century]. Scientific notes of Petrozavodsk State University. 2009; 5:26-31.

10. Ryzhkov LP, Dzyubuk IM, Gorokhov AV, Marchenko LP, Artem'eva NV, Ieshko TA, Ryabinkina MG, Radnaeva VA. The State of the Aquatic Environment and Biota during Operation of Trout Breeding Pond Farms. Vodnye Resursy. 2011; 38(2):239-247.

11. Ryzhkov LP, Dzyubuk IM, Gura VV. Macro-zoobenthos as indicator of water ecosystem condition in the area of cage fish farm influence. Advances in Environmental Biology. 2014; 8(16):15-18. Retrieved from: http://www.aensiweb.com/old/aeb/Special\%209/15-18.pdf

12. Reshetnikov YS. The atlas of freshwater fish of Russia. Vol. I. Moscow: Nauka; 2002. 378 p.

13. Reshetnikov YS, editor. The atlas of freshwater fish of Russia. Vol. II. Moscow: Nauka; 2002. 252 p.

14. Sterligova OP, Ilmast NV, Savosin DS. Cyclostome and freshwater fish of Karelia. Petrozavodsk: Karelian Scientific Center of the Russian Academy of Sciences; 2016. 224 p.

15. Nikolsky GV. Struktura vida i zakonomernosti izmenchivosti ryb [The structure of the species and patterns of fish variability] Moscow: Food industry; 1980. 182 p.

16. Pravdin I F. Rukovodstvo po izucheniyu ryb [The guide to fish study]. Moscow: Food industry; 1966. 376 p 
17. Kafanova VV. Metody opredeleniya vozrasta i rosta ryb [Methods of determining the age and growth of fish]: Handbook. Tomsk: Publishing house of the Tomsk University; 1984. 55 p.

18. Campana SE. Accuracy, precision and quality control in age determination, including a review of the use and abuse of age validation methods. Ecology of freshwater fish. 2005; 5(2):197-242. Available from: doi:10.1111/j.1095-8649.2001.tb00127.x

19. Ivanter EV, Korosov AV. Elementarnaya biometriya [Elementary biometry]: textbook. 3rd ed., rev. and ext. Petrozavodsk: PetrSU Publishing house; $2013.110 \mathrm{p}$.

20. Filatov NN, editor Environmental problems of the Onega Lake. Petrozavodsk: KarSC of RAS; 1999. 293 p.

21. Kukharev VI, Lukin AA, editors.Bioresursy Onezhskogo ozera [The biological resources of the Onega Lake].Petrozavodsk: Karelian Scientific Center of the Russian Academy of Sciences; 2008. 271 p.

22. Ryzhkov LP, Dzyubuk IM. Ekologicheskaya bezopasnost sadkovogo rybovodstva [Environmental safety of cage fish farming]. Petrozavodsk: PetrSU; 2014. 98 p.

23. Forsman A, Tibblin P, Berggren H, Nordahl O, Koch-Schmidt P, Larsson P. Pike Esox lucius as an emerging model organism for studies in ecology and evolutionary biology: a review. Journal of Fish Biology. 2015;87(2):472-479. Available from:doi: $10.1111 / \mathrm{ffb} .12712$ 